\title{
ERRATUM
}

Sumihiro Koyama $\cdot$ Masuo Aizawa

\section{Tissue culture of the deep-sea bivalve Calyptogena soyoae}

\section{Extremophiles (2000) 4:385-389}

On p. 389, in the figure legend of Fig. 5 of the above article, the concentration of IdU in the culture of mantle shells should read $10 \mu \mathrm{M}$ (not $20 \mu \mathrm{M})$.

S. Koyama $(\bowtie) \cdot$ M. Aizawa

Frontier Research Program for Deep-sea Extremophiles, Japan

Marine Science and Technology Center, 2-15 Natsushima-cho,

Yokosuka 237-0061, Japan

Tel. +81-468-67-5542; Fax +81-468-66-6364

e-mail: skoyama@jamstec.go.jp

M. Aizawa

Department of Biological Information, Tokyo Institute of

Technology, Nagatsuta, Yokohama, Japan 